\title{
THE COGNITIVE IMPPAIRMENT AND ITS RELATED FACTORS AMONG FACTORS AMONG ELDERLY HYPERTENSIVE IN TWO RURAL DISTRICTS AREAS, MALAYSIA
}

\author{
Mohamad Rodi Isa ${ }^{1, *}$, Siti Munira Yasin ${ }^{1}$, Mariam Mohamad ${ }^{1}$, Zaliha Ismail ${ }^{1}$ and Zahir izuan Azhar ${ }^{1}$ \\ 'Department of Public Health Medicine, Faculty of Medicine, Universiti Teknologi MARA (UiTM) Sungai Buloh Campus, \\ Jalan Hospital, 47000 Sungai Buloh, Selangor Darul Ehsan.
}

* Corresponding author: Mohamad Rodi Isa

Email: rodi@uitm.edu.my

\begin{abstract}
As cognition declines with age, cognitive impairment rates are expected to increase ranging from $100 \%$ to $300 \%$ in this region. It could be higher among elderly who had any chronic diseases. The aim of the present work was to determine the prevalence and associated factors of cognitive impairment among elderly with hypertension. A clinic-based, cross-sectional study was conducted at several community clinics in Sabak Bernam and Hilir Perak districts from July to December 2015. A total of 480 patients were recruited. The prevalence of cognitive impairment was 13.13\% (95\% Cl: 13.11, 13.15). Factors associated with cognitive impairment among elderly hypertensive were no formal educational level [OR: $3.95(95 \% \mathrm{Cl}: 1.80,8.67)]$; history of high cholesterol [OR: 3.24 (95\% Cl: 1.15, 9.16)]; underweight [adj. OR: 4.88 (95\% Cl: 1.34, 17.67)]; and increasing age [OR: 1.03 (95\% Cl: 1.01 , 1.06)]. Public health policy makers and geriatric practitioners should emphasise on early cognitive function assessment among elderlies who are hypertensive, unemployed, poor educational background, males, high cholesterol level and underweight to enhance the quality of geriatric services. Earlier establishment of diagnosis may prevent from greater rate of decline in cognitive functioning among this vulnerable group.
\end{abstract}

Keyword: screening, cognitive impairment; associated factors; elderly hypertensive

\section{INTRODUCTION}

It is estimated that the elderly population in lower- and middle-income countries are predicted to increase from $60 \%$ in 2001 to $71 \%$ by $2040^{1}$. In Malaysia with over 26 million populations, it is estimated by 2020 that $9.8 \%$ of Malaysia's population will be above 60 years of age with improved healthcare and life expectancy ${ }^{2}$. This increase in elderly population will enviably lead to higher impact on overall healthcare cost.

As cognition declines with age, cognitive impairment rates are expected to increase ranging from $100 \%$ to $300 \%$ in this region. Bigger developing country like Africa, the burden of cognitive impairment and dementia has estimated to cost approximately US\$2.9 billion $^{3}$. To address this financial burden in developing countries, data on the local prevalence of cognitive impairment and its associated risk factors are essential. At present, there are no local studies in estimating the burden of this problem. However, in a recent study among elderlies in Malaysia the prevalence of cognitive impairment among elderlies was $11 \%$, and factors associated with it include unmarried, unemployed, and living alone ${ }^{4}$. In the absence of disease-modifying pharmacotherapy options, decreasing the prevalence of cognitive impairment may be achieved by modifying risk factors or lifestyle. Hence, early identification and management of risk factors may reduce the burden of ideas resulting in significant financial saving to the government.

Studies looking into the association between mental functions and blood pressure were conducted for 60 years back. Earlier studies of cross-sectional in nature used psychomotor assessment such as flicker fusion ${ }^{5}$ and finger tapping ${ }^{6}$. These studies suggested an association between cognitive impairment and hypertension. However, they were inadequately controlled, for example, the selection of participants with only acutely ill ${ }^{7}$ or only with schizophrenia ${ }^{8}$. Later studies often employ more extensive test batteries $^{9-11}$ but still had various methodological problems such as poor control for health status, after administration of diuretics ${ }^{10}$ or other medications ${ }^{11}$.

Subsequent studies were longitudinal ${ }^{12,13}$ but were complicated to interpret due to its relatively high attrition rate during the follow-up periods. However, later, more methodologically sound studies found little influence of hypertension on cognition ${ }^{14,15}$. Nonetheless, some contradicting positive relationships were found between high blood pressure and cognitive impairment in other longitudinal ${ }^{16}$ and crosssectional studies ${ }^{17}$. Although new evidence continues to arise ${ }^{18-20}$, the relationship remains unclear until today and more research is required 
to ascertain this across population with different cultural background and behaviour.

In addition, it is also of great interest to identify the prevalence and risk factors for cognitive impairment among elderlies with hypertensive. This study is one of the studies to date looking into this issue among hypertensive elderlies, as previous studies concentrated on elderlies without co-morbidity. This is required since elderly hypertensive individuals are vulnerable groups that require additional attention. They are dependent on relative for medication reminders, supplies and dosages. Therefore, this group of individuals may be at great risk of morbidity and mortality compared to cognitive impaired elderlies alone. The results of this may benefit public health policy makers in designing the best screening methods of cognitive impairment and appropriate intervention for elderlies with comorbidities. This may contribute towards improvement in their medical condition resulting from earlier detection of cognitive impairment.

Hence, the main aim of this study was to determine the prevalence of cognitive impairment and its associated factors among elderly hypertensive in two rural districts sreas in Malaysia.

\section{METHODS}

\section{Study design and Area}

A clinical-based, cross sectional study involving elderly hypertensive attending several community clinics was conducted at Hilir Perak and Sabak Bernam district areas from July to December 2015. There were 10 community clinics have been choosen in this study where Community Clinic Teluk Intan, Community Clinic Langkap, Community Clinic Hutan Melintang, Community Clinic Sungai Sumun are in the Hilir Perak district, whereas Community Clinic Sungai Besar, Community Clinic Sekinchan, Community Clinic Parit Baru and Community Clinic Sungai Air Tawar are in the Sabak Bernam district area. The community clinics have been selected by using simple random sampling via computer generated EPI INFO6 software.

\section{Sample size calculation}

Sample size was estimated based on the study done by Ko et al. ${ }^{21}$, who found the prevalence of cognitive impairment among elderly in rural community in Jeju Province was $33.1 \%$. By taking $\mathrm{a}=0.05$ and $80 \%$ power of study, using OpenEpi software, the sample size estimation was 341 . By adjusting for $10 \%$ attrition rate, the minimum sample size required in this study was 375 .

\section{Study population and Sampling}

All hypertensive patients confirmed by the medical personnel aged 60 years old and above were invited to participate in our study. The patients were chosen arbitrary using convenience sampling. We excluded those who were illiterate in Malay language and patients who did not able to give consent.

\section{Method of data collection}

A pretested interviewer administered questionnaire was use long with observation to collect data. There were three methods of data collection which were: face to face interview using self-structured questionnaire; review of medical record; and self-administered questionnaire. Face to face interview using selfstructured questionnaire to collect primary data on the socio-demographic, past medical and surgical histories. Patient's medical records were reviewed to counter check the information given by the patients and to obtain information on the past medical and surgical illness and drug histories of the patients. Self-administered questionnaire was to collect the assessment for cognitive impairment.

\section{Assessment for the cognitive impairment}

The cognitive impairment was assessed using The Elderly Cognitive Assessment Questionnaire (ECAQ) to screen for cognitive impairment among elderly hypertensive patients. The ECAQ is derived from items in the Mini-Mental State Examination (MMSE) and Geriatric Mental State Schedule. It consisted of 10 -item that grouped into three categories which are memory (3item), orientation (6-item) and memory-recall (1-item). Each correct answer will earn one mark. The maximum score is 10 and the score with 5 and below was classified as having cognitive impairment. The ECAQ has shown good sensitivity (85.3\%), specificity (91.5\%) and positive predictive value $(82.8 \%)$. Besides that it also shown low miscalculation rate $(10.5 \%)^{22}$. A validated Malay version of ECAQ was used in this study.

\section{Ethical statement}

The protocol of this study was ethically reviewed and approved by the Ethics Committee Universiti Teknologi MARA (UiTM) and permissions were obtained from the Sabak Bernam and Hilir Perak District Health Offices to conduct the study. Oral consent was obtained from the patients and they were informed that their responses would be kept confidential.

\section{Data management and Statistical analysis}

The data was entered and analysed using Statistical Package for Social Science (SPSS) version 20.0 (SPSS Inc, Chicago, IL). The score of cognitive impairment was entered as continuous variables. The prevalence of cognitive impairment was calculated after the score being classified into binary outcome (impairment and no impairment).

The significant level was preset at $a=0.05$. The normality of continuous data was checked via 
Kolmogorov-Smirnov testing and plotting the histogram with normal curve. The normally distributed continuous data was presented in the form of mean values with the corresponding standard deviations. Median values and their corresponding inter-quartile range (IQR) values were presented for the non-normally distributed continuous data. The categorical data were presented in the form of absolute number and their corresponding percentages values.

Analysis using simple logistic regression (SLR) was used to determine the possible associated factors for cognitive impairment by determining the Odds Ratio (OR) and 95\% Confidence intervals for both categorical and continuous datas. All the significant factors in the SLR was further analyzed using backward, stepwise and forward of multiple logistic regression to determine the associated factor to adjust for confounding factors.

\section{RESULTS}

A total of 480 patients involved in the study. However, only 396 patients agreed to participate and gave the response rate of $82.5 \%$. The prevalence of cognitive impairment was $13.13 \%$ (95\% Cl: 13.11, 13.15).

Participants showed a balance number of gender. Table 1 shows the socio-demographic characteristics and their lifestyles of the respondents. The majority were Malays, received formal education until secondary school, staying with others, non-smokers, non-alcoholic and at present either retired or unemployed.

Table 1: Sociodemographic characteristics and their lifestyles of the respondents $(N=396)$

\begin{tabular}{|c|c|c|}
\hline & $\begin{array}{c}\text { Frequency (\%) } \\
\mathrm{N}=396, \mathrm{n}(\%)\end{array}$ & Mean (SD) \\
\hline Age (years) & & $68.82(6.76)$ \\
\hline \multicolumn{3}{|l|}{ Gender: } \\
\hline Male & $195(49.2)$ & \\
\hline Female & $201(50.8)$ & \\
\hline \multicolumn{3}{|l|}{ Ethnicity: } \\
\hline Malay & 303 (76.5) & \\
\hline Chinese & 55 (13.9) & \\
\hline Indian & $38(9.6)$ & \\
\hline \multicolumn{3}{|l|}{ Educational level: } \\
\hline No formal & 94 (23.7) & \\
\hline Formal & $302(76.3)$ & \\
\hline \multicolumn{3}{|l|}{ Occupation: } \\
\hline Employed & $59(14.9)$ & \\
\hline Unemployed & $138(34.8)$ & \\
\hline Housewife & $80(20.2)$ & \\
\hline Retired & $119(30.1)$ & \\
\hline Household income (RM) & & $732.90(497.30)$ \\
\hline \multicolumn{3}{|l|}{ Living arrangement: } \\
\hline Living alone & $42(10.6)$ & \\
\hline Living with others & $354(89.4)$ & \\
\hline \multicolumn{3}{|l|}{ Smoking status: } \\
\hline Non smoker & 284 (71.7) & \\
\hline Current smoker & $52(13.1)$ & \\
\hline Ex-smoker & $60(15.2)$ & \\
\hline \multicolumn{3}{|l|}{ Alcohol status: } \\
\hline Non drinker & 366 (92.4) & \\
\hline Current drinker & $13(3.3)$ & \\
\hline Ex-drinker & $17(4.3)$ & \\
\hline
\end{tabular}


The past medical illness, anthropometric and vital signs of the respondents are shown in Table 2. Majority of the respondents are obese and overweight. The blood pressure is in the normal range.

Table 2: The past medical illness, anthropometric and vital signs of the respondents $(\mathrm{N}=396)$

\begin{tabular}{|c|c|c|}
\hline & $\begin{array}{c}\text { Frequency (\%) } \\
\mathrm{N}=396, \mathrm{n}(\%)\end{array}$ & Mean (SD) \\
\hline Duration of hypertension (year) & & $8.44(7.29)$ \\
\hline \multicolumn{3}{|l|}{ History of diabetes: } \\
\hline Yes & $179(45.2)$ & \\
\hline No & $217(54.8)$ & \\
\hline \multicolumn{3}{|l|}{ History of hypercholesterolemia: } \\
\hline Yes & $136(34.3)$ & \\
\hline No & $260(65.7)$ & \\
\hline \multicolumn{3}{|l|}{ History of ischaemic heart disease: } \\
\hline Yes & $49(12.4)$ & \\
\hline No & $347(87.6)$ & \\
\hline \multicolumn{3}{|l|}{ History of stroke $(n=395)$ : } \\
\hline Yes & $23(5.8)$ & \\
\hline No & $372(94.2)$ & \\
\hline \multicolumn{3}{|l|}{ History of psychiatric illness } \\
\hline Yes & $3(0.8)$ & \\
\hline No & $393(99.2)$ & \\
\hline \multicolumn{3}{|l|}{ Body Mass Index (BMI) $(n=384)$ : } \\
\hline Normal & $86(22.4)$ & \\
\hline Underweight & $18(4.7)$ & \\
\hline Overweight \& Obese & $280(72.9)$ & \\
\hline Systolic bloof pressure (SBP), mmHg: & & $140.35(16.99)$ \\
\hline Diastolic blood pressure (DBP), $\mathrm{mmHg}$ : & & $81.97(10.89)$ \\
\hline Waist circumference, $\mathrm{cm}$ : & & $85.88(12.63)$ \\
\hline Hip circumference, cm: & & $92.75(13.30)$ \\
\hline
\end{tabular}

The associations of socio-demography and medical factors with cognitive impairment among elderly hypertensive are shown in Table 3 and Table 4. Table 5 shows the only significant association factors using simple logistic regression. In simple logistic regression (SLR), it was found that gender, educational level, occupation, history of high cholesterol, history of psychiatric illness, body mass index (BMI), depression status, age, household income, diastolic blood presure (DBP), waist and hip circumferences were found to be significant factors for cognitive impairment in this group of patients. The multiple logistic regression (MlogR) for the associated factor for cognitive impairment among elderly hypertensive is shown in Table 6. After adjusted for confounding factor, the only associated factors were educational level, history of hypercholesterolemia, BMI and age. However, these four factors only can discriminate $84.3 \%$ (95\% Cl: 78.7, 89.9) of having congnitive impairment or not. 
Table 3: Factors associated with cognitive impairment among elderly hypertensive $(\mathrm{N}=396)$

\begin{tabular}{|c|c|c|c|c|}
\hline & $\begin{array}{r}\begin{array}{r}\text { Impairment } \\
(\mathrm{n}=52) \\
\mathrm{n}(\%)\end{array} \\
\end{array}$ & $\begin{array}{r}\text { No Impairment } \\
(\mathrm{n}=344) \\
\mathrm{n}(\%)\end{array}$ & $\begin{array}{r}\text { Chi-square } \\
\text { (df) }\end{array}$ & p-value \\
\hline \multicolumn{5}{|l|}{ Gender: } \\
\hline Male & $180(92.3)$ & $15(7.7)$ & 9.963 & $0.002^{*}$ \\
\hline Female & $164(81.6)$ & 37 (18.4) & $(1)$ & \\
\hline \multicolumn{5}{|l|}{ Ethnicity: } \\
\hline Malay & $265(87.5)$ & $38(12.5)$ & 0.596 & 0.742 \\
\hline Chinese & $46(83.6)$ & $9(16.4)$ & $(2)$ & \\
\hline Indian & $33(86.8)$ & $5(13.2)$ & & \\
\hline \multicolumn{5}{|l|}{ Marital status: } \\
\hline Single & $8(88.8)$ & $1(11.2)$ & 8.824 & $0.056 \#$ \\
\hline Married & $264(90.1)$ & $29(9.9)$ & (3) & \\
\hline Widowed & $66(75.9)$ & $21(24.1)$ & & \\
\hline Divorced \& Separated & $5(71.4)$ & $2(28.6)$ & & \\
\hline \multicolumn{5}{|l|}{ Educational level: } \\
\hline No formal education & $63(67.0)$ & $31(33.0)$ & 42.565 & $<0.001^{*}$ \\
\hline Formal Education & $281(93.0)$ & $21(7.0)$ & (1) & \\
\hline \multicolumn{5}{|l|}{ Occupation: } \\
\hline Employed & $57(96.6)$ & $2(3.4)$ & 16.232 & $0.001^{*}$ \\
\hline Unemployed & $108(78.3)$ & $30(21.7)$ & (3) & \\
\hline Housewife & $70(87.5)$ & $10(12.5)$ & & \\
\hline Retired & $109(91.6)$ & $10(8.4)$ & & \\
\hline \multicolumn{5}{|l|}{ Smoking status: } \\
\hline Non smoker & 241 (84.9) & $43(15.1)$ & 3.992 & 0.136 \\
\hline Current smoker & $49(94.2)$ & $3(5.8)$ & $(2)$ & \\
\hline Ex-smoker & $54(90.0)$ & $6(10.0)$ & & \\
\hline \multicolumn{5}{|l|}{ Alcohol status: } \\
\hline Non-drinker & $320(87.4)$ & $46(12.6)$ & 1.533 & 0.465 \\
\hline Current drinker & $10(76.9)$ & $3(23.1)$ & $(2)$ & \\
\hline Ex-drinker & $14(82.4)$ & $3(17.6)$ & & \\
\hline \multicolumn{5}{|l|}{ History of diabetes } \\
\hline Yes & $155(86.6)$ & $24(13.4)$ & 0.022 & 0.882 \\
\hline No & $189(87.1)$ & $28(12.9)$ & (1) & \\
\hline \multicolumn{5}{|l|}{ History of high cholesterol } \\
\hline 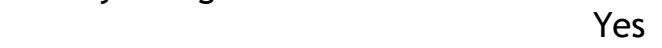 & $126(92.6)$ & $10(7.4)$ & 6.063 & $0.014^{*}$ \\
\hline No & $218(83.8)$ & $42(16.2)$ & (1) & \\
\hline \multicolumn{5}{|l|}{ History of IHD: } \\
\hline Yes & $43(87.8)$ & $6(12.2)$ & 0.039 & 0.844 \\
\hline No & $301(86.7)$ & $46(13.3)$ & (1) & \\
\hline \multicolumn{5}{|l|}{ History of stroke (n=395) } \\
\hline Yes & 17 (93.9) & $6(26.1)$ & 3.770 & 0.052 \\
\hline No & 327 (87.9) & $45(12.1)$ & (1) & \\
\hline \multicolumn{5}{|l|}{ History of psychiatric illness: } \\
\hline Yes & $1(33.3)$ & $2(66.7)$ & 7.595 & $0.047^{*} \#$ \\
\hline No & $343(87.3)$ & $50(12.7)$ & (1) & \\
\hline \multicolumn{5}{|l|}{ Living arrangement: } \\
\hline Living alone & 39 (92.9) & $3(7.1)$ & 1.477 & 0.224 \\
\hline Living with others & $305(86.2)$ & $49(13.8)$ & $(1)$ & \\
\hline \multicolumn{5}{|l|}{ BMI } \\
\hline Underweight & $11(61.1)$ & 7 (38.9) & 17.621 & $0.001^{*}$ \\
\hline Normal & $69(80.2)$ & 17 (19.8) & (3) & \\
\hline Overweight & $138(90.2)$ & $15(9.8)$ & & \\
\hline Obese & $116(91.3)$ & $11(8.7)$ & & \\
\hline \multicolumn{5}{|l|}{ BP status: } \\
\hline Controlled & $162(89.0)$ & $20(11.0)$ & 1.397 & 0.237 \\
\hline Uncontrolled & $181(85.0)$ & $32(15.0)$ & (1) & \\
\hline Depression: & & $22(24.4)$ & & \\
\hline Yes & $68(75.6)$ & $30(9.8)$ & 13.068 & $<0.001^{*}$ \\
\hline No & $276(90.2)$ & & $(1)$ & \\
\hline \multicolumn{5}{|l|}{ Anxiety } \\
\hline Yes & 44 (84.6) & $8(15.4)$ & 0.266 & 0.606 \\
\hline No & $300(87.2)$ & $44(12.8)$ & (1) & \\
\hline
\end{tabular}


Malaysian Journal of Public Health Medicine 2020, Special Volume (1): 282-291

* Statistically significant at $a=0.05, \quad$ Fisher exact's test

Table 4: Factors associated with cognitive impairment among elderly hypertensive $(\mathrm{N}=396)$

\begin{tabular}{|c|c|c|c|c|c|c|}
\hline & $\begin{array}{l}\text { Cognitive } \\
\text { impairment } \\
\text { status }\end{array}$ & $\mathbf{N}$ & Mean (SD) & $\begin{array}{r}t \\
\text { (df) }\end{array}$ & $\begin{array}{l}\text { Mean dif. } \\
(95 \% \mathrm{Cl})\end{array}$ & $\mathrm{p}$-value \\
\hline Age (years) & $\begin{array}{l}\text { No } \\
\text { Yes }\end{array}$ & $\begin{array}{r}344 \\
52\end{array}$ & $\begin{array}{l}67.90(5.95) \\
75.25(8.21)\end{array}$ & $\begin{array}{r}-7.860 \\
(394)\end{array}$ & $\begin{array}{r}-7.35 \\
(-9.19,-5.51)\end{array}$ & $<0.001^{*}$ \\
\hline $\begin{array}{l}\text { Household income } \\
\text { (RM) }\end{array}$ & $\begin{array}{l}\text { No } \\
\text { Yes }\end{array}$ & $\begin{array}{r}296 \\
45\end{array}$ & $\begin{array}{l}932.68(960.77) \\
530.00(392.89)\end{array}$ & $\begin{array}{r}2.774 \\
(339)\end{array}$ & $\begin{array}{r}402.68 \\
(117.11,688.24)\end{array}$ & $0.006^{*}$ \\
\hline $\begin{array}{l}\text { Duration of } \\
\text { hypertension }\end{array}$ & $\begin{array}{l}\text { No } \\
\text { Yes }\end{array}$ & $\begin{array}{r}344 \\
52\end{array}$ & $\begin{array}{l}8.36(7.37) \\
8.87(6.84)\end{array}$ & $\begin{array}{r}-0.464 \\
(394)\end{array}$ & $\begin{array}{r}-0.55 \\
(-2.65,1.64)\end{array}$ & 0.643 \\
\hline $\begin{array}{l}\text { Systolic blood } \\
\text { pressure }\end{array}$ & $\begin{array}{l}\text { No } \\
\text { Yes }\end{array}$ & $\begin{array}{r}343 \\
52\end{array}$ & $\begin{array}{l}138.76(15.66) \\
141.94(18.32)\end{array}$ & $\begin{array}{r}-1.335 \\
(303)\end{array}$ & $\begin{array}{r}-3.18 \\
(-7.87,1.51)\end{array}$ & 0.183 \\
\hline $\begin{array}{l}\text { Diastolic blood } \\
\text { pressure }\end{array}$ & $\begin{array}{l}\text { No } \\
\text { Yes }\end{array}$ & $\begin{array}{r}343 \\
52\end{array}$ & $\begin{array}{l}80.25(11.48) \\
83.69(10.30)\end{array}$ & $\begin{array}{r}-2.043 \\
(393)\end{array}$ & $\begin{array}{r}-3.44 \\
(-6.76,-0.13)\end{array}$ & $0.042^{*}$ \\
\hline $\begin{array}{l}\text { Waist } \\
\text { circumference }\end{array}$ & $\begin{array}{l}\text { No } \\
\text { Yes }\end{array}$ & $\begin{array}{r}332 \\
48\end{array}$ & $\begin{array}{l}89.46(12.45) \\
82.30(12.80)\end{array}$ & $\begin{array}{l}3.714 \\
(378)\end{array}$ & $\begin{array}{r}7.17 \\
(3.37,10.96)\end{array}$ & $<0.001^{*}$ \\
\hline Hip circumference & $\begin{array}{l}\text { No } \\
\text { Yes }\end{array}$ & $\begin{array}{r}332 \\
48\end{array}$ & $\begin{array}{l}95.67(12.56) \\
89.42(14.04)\end{array}$ & $\begin{array}{l}3.177 \\
(378)\end{array}$ & $\begin{array}{r}6.26 \\
(2.39,10.13)\end{array}$ & $0.002^{*}$ \\
\hline
\end{tabular}

* Statistically significant at $a=0.05$, Statistical test: independent $t$-test

Table 5: Simple Logistic Regression (SLR) for the associated factor of cognitive impairment among elderly hypertensive patients

\begin{tabular}{|c|c|c|c|}
\hline Variables & Beta (SE) & p-value & OR $(95 \% \mathrm{Cl})$ \\
\hline \multicolumn{4}{|l|}{ Gender: } \\
\hline Male vs female & $0.99(0.33)$ & $0.002^{*}$ & $2.70(1.43,5.12)$ \\
\hline Educational level & $189\left(\begin{array}{ll}0 & 32\end{array}\right)$ & $<0001 *$ & $658\left(\begin{array}{llll}35 & 12 & 21\end{array}\right)$ \\
\hline Occupation: & $1.07(0.02)$ & -0.001 & 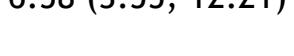 \\
\hline Employed & & 1 & Ref \\
\hline Unemployed & $-2.07(0.75)$ & $0.006^{*}$ & $0.13(0.03,0.55)$ \\
\hline Housewife & $-1.40(0.80)$ & 0.077 & $0.25(0.05,1.17)$ \\
\hline Retired & $-0.96(0.79)$ & 0.225 & $0.38(0.08,1.81)$ \\
\hline History of high cholesterol & & & \\
\hline History of nsychiatric illness: & $0.89(0.37)$ & $0.016^{*}$ & $2.43(1.18,5.01)$ \\
\hline miscory of psyctilatic mess. & $-2.62(1.23)$ & $0.034^{*}$ & $0.07(0.01,0.82)$ \\
\hline Body mass index (BMI) & & & \\
\hline Normal & & 1 & Ref \\
\hline Underweight & $1.29(0.54)$ & $0.016^{*}$ & $3.64(1.28,10.37)$ \\
\hline Overweight\&Obese & $-0.33(0.29)$ & 0.257 & $0.72(0.41,1.27)$ \\
\hline Age & $-0.15(0.02)$ & $<0.001^{*}$ & $0.86(0.82,0.90)$ \\
\hline Household income & $0.01(0.00)$ & $0.004^{*}$ & $1.00(1.00,1.01)$ \\
\hline Diastolic blood pressure (DBP) & $-0.03(0.01)$ & $0.044^{*}$ & $0.98(0.95,0.99)$ \\
\hline Waist circumference & $0.05(0.01)$ & $<0.001^{*}$ & $1.05(1.02,1.08)$ \\
\hline Hip circumference & $0.04(0.01)$ & $0.002^{*}$ & $1.04(1.02,1.07)$ \\
\hline
\end{tabular}

\footnotetext{
${ }^{*}$ Statistically significant at $a=0.05, \mathrm{Cl}=$ Confidence interval; $d f=$ degree of freedom; OR: Odds ratio
} 
Table 6: The Multiple Logistic Regression (MLR) for the associated factor for cognitive impairment among elderly hypertensive patients

\begin{tabular}{|c|c|c|c|}
\hline Variables & Adj. Beta (SE) & p-value & Adj. OR (95\%Cl) \\
\hline \multicolumn{4}{|l|}{ Educational level } \\
\hline $\begin{array}{ll}\text { History of high cholesterol } & \text { No formal vs formal }\end{array}$ & $1.37(0.40)$ & & $3.95(1.80,8.67)$ \\
\hline Yes vs No & $1.18(0.53)$ & $0.027^{*}$ & $3.24(1.15,9.16)$ \\
\hline \multicolumn{4}{|l|}{ BMI } \\
\hline $\begin{array}{r}\text { Normal } \\
\text { Underweight } \\
\text { Overweight \& Obese }\end{array}$ & $\begin{array}{l}1.59(0.66) \\
-0.20(0.33) \\
0.99(0.03)\end{array}$ & $\begin{array}{c}1 \\
0.016^{*} \\
0.545 \\
<0.001^{*}\end{array}$ & $\begin{array}{c}\text { Ref } \\
4.88(1.34,17.67) \\
0.82(0.42,1.57) \\
1.03(1.01,1.06)\end{array}$ \\
\hline \multicolumn{4}{|c|}{$\begin{array}{l}\text { * Statistically significant at } a=0.05 \\
\text { Cl=Confidence interval; } d f=\text { degree of freedom; OR: Odds ratio } \\
P \text { value }=p \text { value of wald test } \\
\text { Hosmer and Lemeshow test }=0.560 \\
\text { Receiver operating Characterestic }(R O C) \text { curve }=84.3(95 \% \mathrm{Cl}: 78.7,89.9) \\
\text { Specificity of the model }=97.5 \% \\
\text { Overall percentage of classification }=86.2 \% \\
\text { Multiple logistic regression(no multicollinearity). } \\
\text { All assumptions are met. OR= odds ratio based on exponential beta }\end{array}$} \\
\hline
\end{tabular}

\section{DISCUSSION}

This study was the first to date looking into prevalence of cognitive impairment among elderlies diagnosed with hypertension. The prevalence obtained from this study was $(95 \% \mathrm{Cl}$ : $13.11,13.15)$ which was almost the same like those without hypertension, ranging from 3.5 $30.3 \% 23-25$.

Our initial logistic regression clearly showed that males had higher cognitive impairment as compared to females, but was not significant in the multivariate analysis. This initial finding was in contrast to non hypertensive elderlies in the general population in other studies ${ }^{26-27}$. We suspect the reasons for higher scores among males might be difference in the age between male and female subjects and usage of cognitive skills during working life. There existed a hypothesis that mental stimulation may delay the onset of cognitive impairment ${ }^{28}$. Nonetheless, further research is possibly needed to determine gender differences which may exist among elderly hypertensives.

Studies revealed that poor literacy level was correlated with greater cognitive impairment ${ }^{29}$. Our study showed a similar pattern. The number of elderlies with informal education in our study was rather high $(18 \%)$. This may be attributed to Malaysia achieving independence from British colonosation only after 1957. Malaysians born prior to independence had lack of access to proper education system ${ }^{30}$. Furthermore, to enhance the findings, the prevalence of cognitive impairment was found to be inversely related to employment status. Being a retiree, housewife and unemployed is protective against developing cognitive impairment among this elderlies with hypertension. Other socioeconomic status related variables such as, living alone and social support were found to be insignificant as compared to studies in elderlies without hypertensives ${ }^{26}$.

Although our findings also revealed that age may be correlated with cognitive impairment, but we may not be able to ascertain the age of onset of cognitive impairment due to the cross sectional nature of our study. Therefore, the slight variation that existed between those with or without hypertensives should call for futher research of longitudinal in nature. This is to estimate the approximate exact age when cognitive impairment has actually kicked, among those who are employed or otherwise. In addition, there is also a plausible hypothesis relating to our findings among this group.

Previous research had demonstrated that antihypertensive medications played an important role. It has been suggested that longstanding hypertension starting in midlife is linked to the development of later dementia and cognitive impairment. On the contrary, elderly patients who developed late hypertension are less prone to the development of cognitive impairment and dementia. This seemingly paradoxical effect may possibly be due to the protective role of high blood pressure in cerebral perfusion in elderlies with stiffer arteries and the continuous decline in blood pressure as a result of dementia/poor cognitive function ${ }^{31,32}$.

Our findings also revealed that lifestyle habits such as BMI and cholesterol were also significantly associated with cognitive impairment in the elderly hypertensive. This corraborates with the notion of the positive 
relationship between good physical activity and slower cognitive decline ${ }^{33}$. It is also to no surprise that underweight hypertensive elderlies have four fold risk of having poor cognitive function when compared to normal weight individuals. We suspect that this may be related to poor nutritional intake of this group of individuals. Moreover, elderlies with high cholesterol levels had higher risk of being cognitively impaired. This is consistent with other findings of the relationship between cholesterol level and low cognitive function ${ }^{34}$. Hence, lowering the cholesterol levels and maintaining healthy diet may be potential strategies to prevent the development of cognitive impairment among elderly hypertensives.

\section{STUDY LIMITATIONS, RECOMMENDATIONS AND CONCLUSION}

Several other limitations worth mentioning in this study. Firstly, the small number of participants was a major limitation, especially since we could not categorize our subjects into categories for age, blood pressure levels and education levels. This small number of participants and comprising of only two districts limit its generalizability to the whole Malaysian rural communities. Furthermore, most of our participants were Malay since the two districts were Malay predominant, which may not be generalized to communities with Chinese or Indian predominance. Future studies would benefit from a bigger sample size and involving whole Malaysian rural communities, segregated by different race. Secondly, assessment of cognitive impairment only used one instrument. Although the ECAQ is a reliable instrument, the most commonly used instrument for screening of cognitive status in elderly patients is $\mathrm{MMSE}^{35}$. Hence, it would be an advantage to use two instruments instead of one in later studies. In addition, utilizing an instrument that was less dependent on education level of subjects in study would be more desirable. Thirdly, some of the participants were illiterate, and questionnaires were being filled by their family members. Similarly, those which had shown cognitive impairment may subject to inaccurate information if the questionnaires were filled solely by the elderly. The authors recommend that in subsequent similar studies, the questionnaire is to be filled up by solely by the family members to reduce bias.

This study has implications for the aging societies, especially those with concurrent medical conditions. Given the high percentage of cognitive impairment among the elderlies, public health policy makers should emphasize on improving the current management of mental health among the elderlies with medical problems. Such efforts may include improving the present mental health in geriatric services, building more elderly homes, and educating the caregivers and family members on proper geriatric care of patients with cognitive impairment.

When planning for improved quality geriatric services, our results conclude that public health policy makers and geriatric practitioners must give priority to assess cognitive function among individuals who are hypertensive, unemployed, poor education background, males, high cholesterol level and underweight. These individuals with high risk of cognitive impairment could also benefit from earlier cognitive screening and proper mental health care. Earlier establishment of diagnosis may prevent from greater rate of decline in cognitive functioning among this vulnerable group and improve their quality of life.

\section{ACKNOWLEDGEMENTS}

We would like to acknowledge all patients who participated in the study. This study was partly funded by FRGS grant [600-RMI/FRGS 5/3 $(38 / 2013)]$. We are also thankful to Ministry of health for providing valuable information for this study.

\section{CONFLICT OF INTEREST STATEMENT}

None

\section{REFERENCES}

1. Dobriansky PJ, Suzman RM, Hodes RJ. Why Population Aging Matters: A Global Perspective. National Institute on Aging, National Institutes of Health, US Department of Health and Human Services, US Department of State 2007.

https://www.nia.nih.gov/research/p ublication/why-population-agingmatters-global-perspective.

2. Mafauzy M. The Problems and Challenges of the Aging Population of Malaysia. The Malaysian Journal of Medical Sciences 2000;7(1):1-3.

3. Kalaria $\mathrm{RN}$, Maestre GE, Arizaga R, Friedland RP, Galasko D, Hall K, Luchsinger JA, Ogunniyi A, Perry EK, Potocnik F, Prince $M$, Stewart $R$, Wimo A, Zhang ZX, Antuono P, World Federation of Nuerology Dementia Research Group. Alzheimer's Disease and Vascular Dementia in Developing Countries: Prevalence, Management, and Risk Factors. The Lancet Neurology 2008;7(9): 812-826.

4. Rashid AK, Azizah AM, Rohana S. Cognitive Impairment Among The 
Elderly Malays Living In Rural Malaysia. Med J Malaysia 2012;67(2):187-189

5. Enzer N, Simonson E, Blankstein SS. Fatigue of Patients with Circulatory Insufficiency, Investigated by Means of the Fusion Frequency of Flicker. Ann Intern Med 1942;16:702-707.

6. Simonson E, Enzer N. State of Motor Centers in Circulatory Insufficiency. Archives of Internal Medicine $1941 ; 68(3): 498-512$.

7. Jalavisto $E$. On the Interdependence of Circulatory-Respiratory and NeuralMental Variables. Gerontology 1964;10(1):31-37.

8. King HE. (1956). Comparison of Fine Psychomotor Movement by Hypertensive and Hypotensive Subjects. Perceptual and Motor Skills 1956;6:199-204.

9. Pentz CA III, Elias MF, Wood WG, Schultz NA, Dineen J. Relationship of Age and Hypertension to Neuropsychological Test Performance. Experimental Aging Research 1979;5(4):351-372.

10. Schultz NR Jr, Dineen JT, Elias MF, Pentz CA III, Wood WG. WAIS Performance for Different Age Groups of Hypertensive and Control Subjects During the Administration of a Diuretic. Journal of Gerontology 1979;34(2):246-253.

11. Shapiro AP, Miller RE, King HE, Ginchereau EH, Fitzgibbon K. Behavioral Consequences of Mild Hypertension. Hypertension 1982;4(3):355-360.

12. Hertzog C, Schaie KW, Gribbin K. Cardiovascular Disease and Changes in Intellectual Functioning from Middle to Old Age. Journal of Gerontology 1978;33(6):872-883.

13. Wilkie F, Eisdorfer C. Intelligence and Blood Pressure in the Aged. Science 1971 172(3986):959-962.

14. Schultz Jr NR, Elias MF, Robbins MA, Streeten DH, Blakeman N. A Longitudinal Study of the Performance of Hypertensive and Normotensive Subjects on the Wechsler Adult Intelligence Scale. Psychology and Aging 1989;4(4):496-499.
15. Schultz NR, Elias MF, Robbins MA, Streeten DH, Blakeman N (1986). A longitudinal Comparison of Hypertensives and Normotensives on the Wechsler Adult Intelligence Scale: Initial Findings. Journal of Gerontology 1986;41(2):169-175.

16. Kleinman KM, Goldman H, Snow MY, Korol B. Relationship Between Essential Hypertension and Cognitive Functioning II: Effects of Biofeedback Training Generalize to Non-Laboratory Environment. Psychophysiology 1977;14(2):192-197.

17. Starr JM, Whalley LJ, Inch S, Shering P. Blood Pressure and Cognitive Function in Healthy Old People. Journal of the American Geriatrics Society 1993:41(7):753-756.

18. Gelber RP, Ross GW, Petrovitch $H$, Masaki KH, Launer LJ, White LR. Antihypertensive Medication Use and Risk of Cognitive Impairment: the Honolulu-Asia Aging Study. Neurology 2013;81(10):888-895.

19. Peters R, Beckett N, Fagard R, Thijs L, Wang JG, Forette F, Pereira L, Fletcher A, Bulpitt C. Increased Pulse Pressure Linked to Dementia: Further Results from the Hypertension in the Very Elderly Trial - HYVET. J Hypertens 2013;31(9):1868-1875.

20. Qiu C, Winblad B, Fratiglioni L. The Age-Dependent Relation of Blood Pressure to Cognitive Function and Dementia. The Lancet Neurology 2005;4(8):487-499.

21. Ko K, Jung $M$, Hong S. Prevalence of Cognitive Impairment and Related Factors Among the Elderly in Rural Communities of Jeju Province. Journal of Korean Academy of Nursing, 2003;33(4):503-509.

22. Kua E, Ko S. A Questionnaire to Screen for Cognitive Impairment among Elderly People in Developing Countries. Acta Psychiatrica Scandinavica 1992;85(2):119-122.

23. Feldman H, Levy A, Hsiung GY, Peters K, Donald A, Black S, Bouchard RW, Gauthier SG, Guzman DA, Hogan DB, Kertesz A, Rockwood K. (2003). A Canadian Cohort Study of Cognitive Impairment and Related Dementias (ACCORD): Study Methods and Baseline Results. Neuroepidemiology 2003;22(5):265-274. 
24. Liu Z, Albanese E, Li S, Huang Y, Ferri C, Yan F, Sousa R, Dang W, Prince M. Chronic Disease Prevalence and Care among the Elderly in Urban and Rural Beijing, China - A 10/66 Dementia Research Group Cross-sectional survey. BMC Public Health, 2009;9:394.

25. Sharma D, Mazta S, Parashar A. Prevalence of Cognitive Impairment and Related Factors among Elderly: A population-based Study. Journal of Dr. NTR University of Health Sciences 2013;2(3):171-176.

26. Kumar N, Sudhakar T. Prevalence of Cognitive Impairment and Depression among Elderly Patients Attending the Medicine Outpatient of a Tertiary Care Hospital in South India. International Journal of Research in Medical Sciences 2013;1(4):359-364.

27. Laks J, Batista EMR, Guilherme ERL, Contino ALB, Faria MEV, Rodrigues CS, Engelhardt $E$. Prevalence of Cognitive and Functional Impairment in Community-Dwelling Elderly: Importance of Evaluating Activities of Daily Living. Arquivos de Neuropsiquiatria, 2005;63(2-A):207-212.

28. Krishnaswamy S. Psychiatric Problems Among the Elderly in Malaysia. Medical Journal of Malaysia 1997;52(3):222-225.

29. Paúl C, Ribeiro O, Santos P. Cognitive Impairment in Old People Living in the Community. Archives of Gerontology and Geriatrics 2010;51(2):121-124.

30. Sato M. Education, Ethnicity and Economics: Higher Education Reforms in Malaysia 1957-2003. NUCB Journal of Language Culture and Communication 2005;7(1):3-88.

31. Duron E, Hanon O. Vascular Risk Factors, Cognitve Decline, and Dementia. Vascular Health and Risk Management 2008;4(2):363-381.

32. Kloppenborg RP, van den Berg E, Kappelle LJ, Biessels GJ. Diabetes and Other Vascular Risk Factors for Dementia: Which Factor Matters Most? A Systematic Review. European Journal of Pharmacology 2008;585(1):97-108.

33. Laurin D, Verreault R, Lindsay J, MacPherson K, Rockwood K. Physical
Activity and Risk of Cognitive Impairment and Dementia in Elderly Persons. Archives of Neurology 2001;58(3):498-504.

34. Yaffe K, Barrett-Connor E, Lin F, Grady D. Serum Lipoprotein Levels, Statin Use, and Cognitive Function in Older Women. Archives of Neurology 2002;59(3):378-384

35. Folstein MF, Folstein SE, McHugh PR. "Mini-Mental State": A Practical Method for Grading the Cognitive State of Patients for the Clinician. Journal of Psychiatric Research, 1975;12(3):189-198. 